BHUMI: Jurnal Agraria dan Pertanahan

Received: November 15, 2021; Reviewed: 21 November, 2021; Accepted: November 29, 2021.

To cite this article: Tarfi, A \& Amri, I. (2021). Reforma Agraria sebagai Jalan Menuju Perdamaian yang Berkelanjutan di Aceh, Bhumi, Jurnal Agraria dan Pertanahan, 7 (2), 210-225.

DOI: 10.31292/bhumi.v7i2.509

Copyright: @2021 Akhyar Tarfi, Ikhwan Amri. All articles published in Jurnal Bhumi are licensed under a Creative Commons Attribution-ShareAlike 4.o International license.

Research Article

\title{
REFORMA AGRARIA SEBAGAI JALAN MENUJU PERDAMAIAN YANG BERKELANJUTAN DI ACEH
}

\author{
Akhyar Tarfi ${ }^{1 *}$ \& Ikhwan Amri ${ }^{2}$ \\ ${ }^{1,2}$ Kantor Wilayah Badan Pertanahan Nasional Provinsi Aceh \\ Jl. Teuku Nyak Arief, Lamgugob, Syiah Kuala, Kota Banda Aceh, Aceh 23115 \\ *Koresponden E-mail: tarfiakhyar@gmail.com
}

\begin{abstract}
The signing of the Helsinki Memorandum of Understanding (MoU) in 2005 marked the end of the Indonesian government's decades-long conflict with the Free Aceh Movement. One of the deals in the Helsinki MoU is to provide farming land to former combatants, amnestied political prisoners, and conflict victims as a form of reintegration and livelihood restoration. However, this activity did not run effectively for a dozen years after the peace deal due to the absence of regulations and authorities in its implementation. Based on this background, this paper examines the role of Agrarian Reform on the policy of agricultural land provision to the people related to the Aceh conflict. This research used a qualitative approach, and relied on observational data and literature review. Agrarian Reform can be an alternative strategy for post-conflict peacebuilding. The concept of asset reform and access reform offered in the Agrarian Reform can be adopted to realize the allocation of agricultural land by the mandate of the Helsinki MoU. The main problems found so far are that there is no regulation regarding the granting of land rights in the law, authority, and several obstacles in its implementation. This paper also provides a crucial lesson that proper agrarian policy contributes to the prevention of recurring conflicts that have the potential to cause national disintegration.
\end{abstract}

Keywords: Agrarian Reform, Free Aceh Movement, Helsinki MoU, Land Redistribution, Peacebuilding

Intisari : Penandatanganan Momerandum of Understanding (MoU) Helsinki pada tahun 2005 menandai berakhirnya konflik pemerintah Indonesia dengan Gerakan Aceh Merdeka selama beberapa dekade. Salah satu kesepakatan di dalam MoU Helsinki adalah menyediakan tanah pertanian kepada mantan kombatan, tahanan politik yang memperoleh amnesti, dan korban konflik sebagai bentuk reintegrasi dan pemulihan penghidupan. Namun, kegiatan ini tidak berjalan secara efektif selama belasan tahun setelah perjanjian damai karena belum adanya regulasi dan kewenangan dalam pelaksanaannya. Berdasarkan latar belakang tersebut, tulisan ini mengkaji peran Reforma Agraria terhadap kebijakan penyediaan tanah pertanian untuk masyarakat yang berkaitan dengan konflik Aceh. Penelitian ini menggunakan pendekatan kualitatif, serta mengandalkan data observasi dan tinjauan literatur. Reforma Agraria dapat menjadi strategi alternatif pembangunan perdamaian pasca-konflik. Konsep penataan aset dan penataan akses yang ditawarkan di dalam Reforma Agraria dapat diadopsi untuk merealisasikan alokasi tanah pertanian sesuai amanah MoU Helsinki. Permasalahan-permasalahan utama yang ditemukan selama ini adalah belum adanya pengaturan mengenai pemberian hak atas tanah tersebut di dalam peraturan perundang-undangan, kewenangan, dan sejumlah hambatan dalam pelaksanaannya. Tulisan ini juga memberikan pelajaran penting bahwa kebijakan agraria yang tepat dapat berkontribusi terhadap pencegahan konflik berulang yang dapat berpotensi menyebabkan disintegrasi bangsa.

Kata Kunci: Gerakan Aceh Merdeka, MoU Helsinki, Pembangunan Perdamaian, Redistribusi Tanah, Reforma Agraria 


\section{A. Pendahuluan}

Tanah, sebagai aset alam, memiliki fungsi yang esensial bagi kehidupan manusia, seperti sarana tempat tinggal dan sumber mata pencaharian. Namun, tekanan antropogenik saat ini telah memunculkan berbagai tantangan terhadap akses dan pemanfaatan tanah (Ruhimat, 2015; Mwesigye \& Matsumoto, 2016). Tata kelola tanah yang tidak mengedepankan asas keadilan dapat menyebabkan kondisi sosial yang tidak stabil. Berkaca dari pengalaman-pengalaman di luar negeri (khususnya Global South), ketegangan berbasis etnis dan konflik bersenjata pun seringkali bersumber dari permasalahan agraria (Krieger \& Meierrieks, 2016). Pada situasi yang lebih ekstrem, konflik skala kecil dapat bertransformasi menjadi ancaman terhadap stabilitas keamanan nasional.

Konflik dan perang juga menyebabkan konsekuensi yang tidak diinginkan terhadap tanah. Berbagai bentuk kegiatan militer, misalnya penanaman ranjau, berdampak pada kerusakan kualitas tanah dan degradasi lingkungan (Certini et al., 2013). Konflik juga mendorong masyarakat untuk bermigrasi secara terpaksa dari tempat tinggalnya menuju ke wilayah yang lebih aman (Eklund et al., 2017). Dua hal yang disebutkan di atas berkontribusi terhadap fenomena penelantaran tanah (land abandonment). Tidak jarang, tanah yang ditinggalkan dan tidak dimanfaatkan oleh pemiliknya diakuisisi oleh orang lain, yang tentunya dapat meningkatkan kompleksitas penyelesaian konflik itu sendiri.

Di banyak negara yang bergantung pada pertanian sebagai sumber penghidupan, tanah sering dimasukkan ke dalam bahan negosiasi untuk gencatan senjata, demobilisasi, dan reintegrasi (Unruh \& Williams, 2013). Di sinilah muncul kesempatan untuk mengidentifikasi akar konflik yang berkaitan dengan pengelolaan sumberdaya alam dan menata kembali kebijakan agraria yang tepat dalam rangka mencapai keadilan sosial dan pembangunan ekonomi. Situasi perdamaian tahap awal relatif rapuh sehingga diperlukan segera pertimbangan yang matang untuk membangun kembali kebijakan pertanahan yang ideal. Sejalan dengan pernyataan tersebut, Pritcard (2013) menyebutkan bahwa pembaruan agraria adalah salah satu elemen utama dari pembangunan perdamaian.

Provinsi Aceh pernah mengalami sejarah panjang berkaitan dengan konflik separatis yang diinisasi oleh Gerakan Aceh Merdeka (GAM) sejak tahun 1976. Deklarasi kemerdekaan Aceh oleh GAM berasal dari keyakinan akan eksistensi Aceh sebagai negara yang diakui secara internasional, dengan merujuk pada alasan historis selama masa kolonialisme (Schulze, 2004). Meskipun demikian, perlu dipahami bahwa gerakan tersebut juga berakar dari perasaan kecewa terhadap hasil eksploitasi sumberdaya alam oleh pemerintah pusat yang dinilai tidak memberikan manfaat kesejahteraan nyata bagi masyarakat Aceh (Wennmann \& Krause, 2009). Konflik berlangsung dalam tiga fase dan bereskalasi secara intensif di hampir seluruh wilayah Aceh, terutama kawasan rural (Gambar 1). Rentetan kekerasan yang terjadi telah menyebabkan instabilitas wilayah, timbulnya jumlah korban jiwa yang besar, kerusakan infrastruktur, hingga terdisrupsinya pembangunan dalam jangka waktu yang panjang.

Penandatanganan Momerandum of Understanding (MoU) Helsinki pada tahun 2005 menandai berakhirnya konflik berkepanjanganantara GAM dan pemerintah Indonesia. Hal ini menjadi langkahawal untuk membangkitkan kembali Aceh dari keterpurukan setelah berbagai usaha negosiasi perdamaian sebelumnya (seperti Cessation of Hostilities Agreement tahun 2003) gagal dilaksanakan. Keberhasilan mediasi konflik tersebut terbentuk setelah tercapainya kepercayaan dalam mempertemukan poin kesepakatan antarpihak sekaligus memperbaiki kesejahteraan masyarakat Aceh. Di samping itu, peristiwa tsunami katastropik tahun 2004 turut menjadi katalis perdamaian (Zeccola, 2011). 


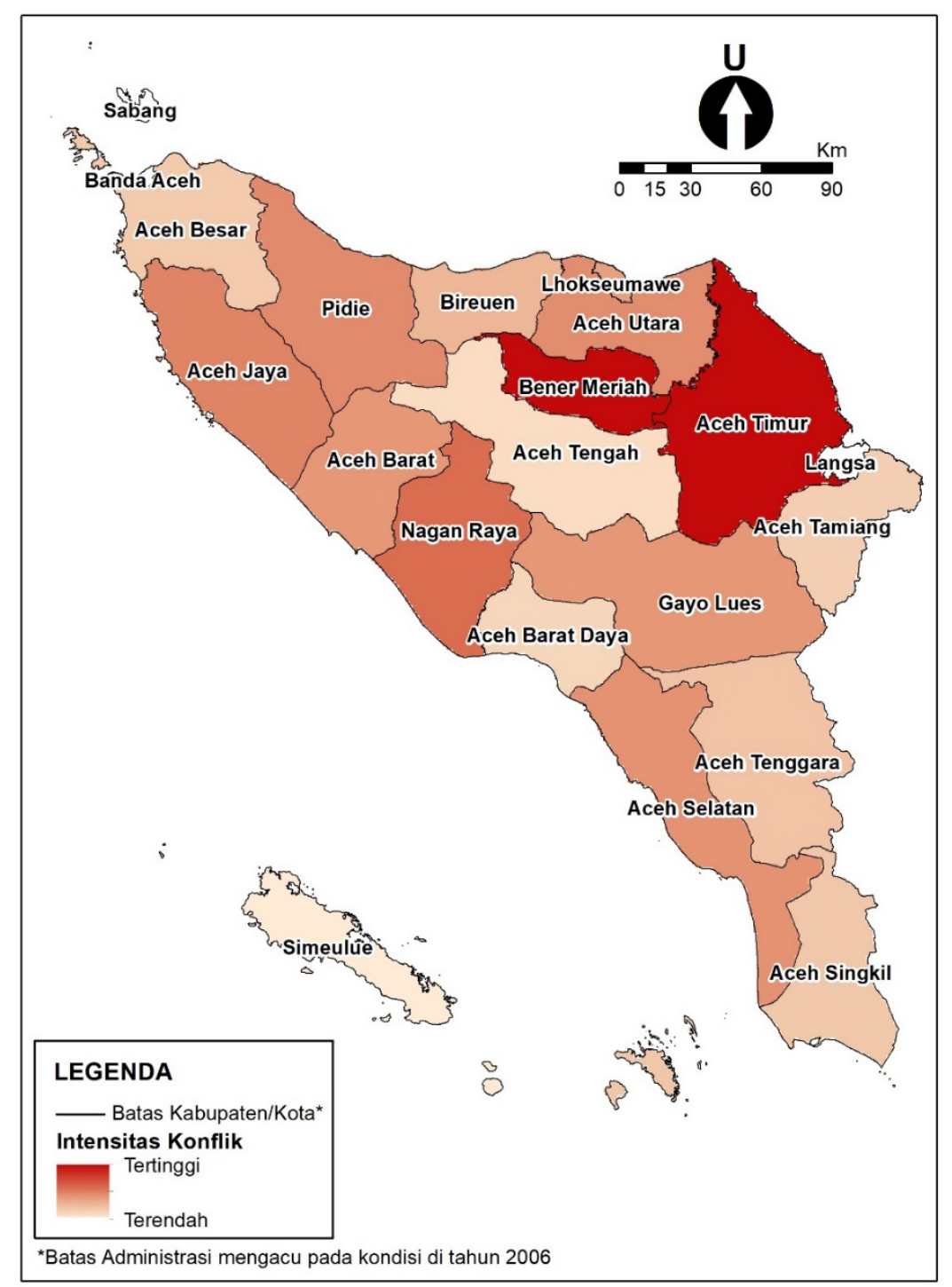

Gambar 1. Persebaran Intensitas Konflik GAM-Pemerintah Indonesia Sumber: World Bank (2007) yang dimodifikasi

Seiring dengan berakhirnya konflik yang berkepanjangan, Provinsi Aceh berhasil memperoleh status otonomi khusus, baik di bidang penyelenggaraan pemerintahan, politik, maupun ekonomi. Pemerintah Indonesia juga telah berjanji akan mengalokasikan tanah pertanian dan dana yang memadai kepada semua mantan kombatan, tahanan politik (tapol) yang memperoleh amnesti, dan rakyat sipil yang dapat menunjukkan kerugian yang jelas, sebagaimana disebutkan secara eksplisit pada MoU Helsinki ayat 3.2.5. Kesepakatan ini pada dasarnya bukan hanya ditujukan untuk memperlancar reintegrasi kelompok separatis ke dalam masyarakat, tetapi juga untuk memulihkan kondisi perekonomian dan penghidupan bagi masyarakat yang terlibat dan terdampak akibat konflik.

Selama 15 tahun setelah penandatanganan MoU Helsinki, realisasi redistribusi tanah pertanian pascakonflik untuk subjek-subjek yang berhak masih belum terselesaikan. Di saat rekonstruksi pascatsunami berhasil merestorasi dan memulihkan kawasan terdampak bencana secara signifikan (Resosudarmo, 2017; Amri \& Giyarsih, 2021), pemulihan kondisi sosial ekonomi masyarakat yang berhubungan dengan konflik justru berjalan relatif lambat. Padahal, Provinsi Aceh mendapatkan kucuran dana melimpah dari pemerintah serta organisasi kemanusiaan lokal dan internasional untuk kepentingan rekonstruksi kedua bencana tersebut, meskipun proses formalnya berjalan secara terpisah (Harrowell \& Özerdem, 2019). 
Pemeliharaan perdamaian sejatinya merupakan salah satu tindakan preventif terhadap munculnya konflik berulang (recurrence conflict) sehingga proses ini dapat berjalan beriringan dengan pencegahan konflik (Trijono, 2009). Konflik-konflik baru rentan muncul ke permukaan apabila kesepakatan damai tidak berhasil diimplementasikan. Oleh karena itu, kebijakan redistribusi tanah pertanian pascakonflik harus segera diwujudkan karena reintegrasi dan peningkatan kesejahteraan merupakan kunci dari perdamaian yang stabil dan berkelanjutan (Nazaruddin et al., 2016).

Tulisan ini mencoba mengangkat isu redistribusi tanah pertanian pascakonflik di Aceh melalui perspektif reforma agraria. Pembahasan terkait redistribusi tanah di Indonesia tidak dapat dilepaskan dari reforma agraria karena kebijakan tersebut merupakan inti dari reforma agraria, sebagaimana mengacu pada Undang-Undang Nomor 5 Tahun 1960 tentang Peraturan Dasar Pokok-Pokok Agraria atau UUPA (Nurjannah, 2014). Tujuan utama reforma agraria adalah mengurangi ketimpangan kepemilikan dan penguasaan atas tanah. Berdasarkan pada hal tersebut, reforma agraria untuk pemeliharaan perdamaian pascakonflik bukan hal yang lazim diterapkan di Indonesia. Meskipun demikian, program tersebut dipercaya dapat berjalan selaras dengan kebijakan redistribusi tanah pascakonflik di Aceh karena memiliki outcome yang serupa yaitu meningkatkan kesejahteraan masyarakat.

Kesepakatan damai terbukti dapat menstabilkan iklim politik dan memacu pembangunan sosial ekonomi yang lebih baik di Provinsi Aceh. Namun, hingga saat ini progres redistribusi tanah pertanian untuk tiga kluster subjek (mantan kombatan, tahanan politik yang memperoleh amnesti, dan korban konflik) belum terdokumentasi dan dipelajari oleh studi ilmiah manapun. Berdasarkan kesenjangan penelitian tersebut, tulisan ini bertujuan untuk mengkaji konsep dan pelaksanaan redistribusi tanah pertanian pascakonflik di Provinsi Aceh dengan menempatkan perhatian utama pada program reforma agraria.

\section{B. Metode}

Penelitian ini bersifat kualitatif. Di dalam penelitian kualitatif, peneliti merupakan instrumen utama di dalam pengumpulan dan analisis data (Mohajan, 2018). Data primer penelitian ini dikumpulkan dari hasil observasi dan pengalaman peneliti selama menangani dan terlibat dengan kegiatan redistribusi tanah. Data tersebut diperkuat oleh tinjauan literatur, termasuk buku, jurnal ilmiah, bahan hukum, dan laporan-laporan Badan Pertanahan Nasional (BPN) yang relevan dengan topik penelitian. Teknik analisis data menggunakan pendekatan deskriptif. Penyajian data kualitatif umumnya berupa teks naratif, tetapi dapat pula divisualisasi dalam bentuk tabel, grafik, diagram, dan sebagainya. Kegiatan analisis difokuskan pada konteks konsep dan penerapan Reforma Agraria di dalam pembangunan perdamaian di Aceh.

\section{Hasil dan Pembahasan}

\section{Konsep Reforma Agraria untuk Masyarakat Pascakonflik di Aceh}

Sejak awal kemerdekaan, Indonesia sudah mulai menggagas pembaruan di bidang agraria. Landasan konstitusionalnya tertera di Pasal 33 Ayat (3) Undang-Undang Dasar 1945 bahwa: "Bumi dan air dan kekayaan alam yang terkandung di dalamnya dikuasai oleh negara dan dipergunakan untuk sebesarbesar kemakmuran rakyat". Praktik hukum agraria kolonial selama puluhan tahun telah mengorbankan kesejahteraan rakyat dan cenderung menciptakan ketimpangan dalam hal penguasaan lahan pertanian. Tidak heran, sejumlah aksi "revolusi sosial" kerap terjadi menyambut proklamasi kemerdekaan sehingga pemerintah terpaksa mengendalikannya dengan reforma agraria dalam skala kecil (Wiradi, 2009). Setelah melewati proses diskusi yang panjang, maka lahirlah hukum agraria nasional yaitu UUPA. Walaupun UUPA dikritik karena terkesan membatasi persoalan agraria pada lingkup pertanahan saja 
(Puri et al., 2014), produk hukum ini mengawali pemerintah untuk merestrukturisasi penguasaan, pemilikan, penggunaan, dan pemanfaatan sumber-sumber agraria.

Pelaksanaan reforma agraria di Indonesia secara historis mengalami pasang surut. Masing-masing rezim politik mendesain dan mempraktikkannya dengan cara yang berbeda (Salim \& Utami, 2019). Pada masa Orde Lama, land reform digagas untuk memperbaiki persoalan agraria dengan berorientasi pada distribusi lahan pertanian ke buruh tani atau petani gurem. Reforma agraria sempat kehilangan arah pada masa Orde Baru karena tekanan politik. Kebijakan sektoral pengelolaan sumberdaya alam yang dibuat pun berlawanan dengan prinsip yang dibangun oleh UUPA. Kesempatan menghidupkan kembali reforma agraria yang nyata baru muncul sejak dimulainya era Reformasi. Lahirnya Ketetapan Majelis Permusyawaratan Rakyat Nomor IX Tahun 2001 tentang Pembaharuan Agraria dan Pengelolaan Sumberdaya Alam menjadi tonggak kebangkitan semangat untuk memperbaiki kesalahan kebijakan pengelolaan sumber-sumber agraria. Reforma agraria juga resmi dimasukkan sebagai bagian dari rencana pembangunan jangka panjang nasional mulai dari tahun 2005 hingga 2025 dan rencana pembangunan jangka menengah nasional mulai dari tahun 2020 hingga tahun 2024.

Karakteristik khusus reforma agraria pada era reformasi (sampai saat ini) adalah adanya land reform plus, dimana skema kebijakan ini menggabungkan penataan aset (asset reform) dengan penataan akses (access reform). Asset reform bertujuan untuk menata kembali struktur penguasaan, pemilikan, penggunaan, dan pemanfaatan tanah yang lebih adil; sementara access reform bertujuan untuk memberdayakan masyarakat melalui pemberian bantuan modal dan lainnya yang berbasis pada pemanfaatan tanah. Fondasi skema tersebut pertama kali dipopulerkan ketika masa Presiden Susilo Bambang Yudhoyono. Konsep land reform plus selanjutnya disempurnakan oleh Presiden Joko Widodo, ditandai dengan rencana pelaksanaan reforma agraria terhadap 9 juta hektare sejak tahun 2015 dan keberhasilan dalam menerbitkan Peraturan Presiden Nomor 86 Tahun 2018 tentang reforma agraria (biasanya disebut sebagai Perpres 86/2018). Target reforma agraria dibagi secara proporsional untuk legalisasi aset dan redistribusi tanah. Kegiatan yang disebutkan terakhir dipandang lebih strategis daripada yang satunya karena bersentuhan langsung dengan cita-cita reforma agraria. Sasaran objek tanah yang akan diredistribusi tidak lagi berfokus pada tanah negara, tetapi juga bersumber dari pelepasan kawasan hutan.

Pelaksanaan penataan aset melalui redistribusi tanah di Aceh memiliki kekhususan dalam hal kriteria subjek yang tidak mengacu pada peraturan agraria nasional yang berlaku. MoU Helsinki mengamanatkan penyediaan tanah pertanian untuk masyarakat yang terlibat dengan GAM dan korban konflik. Sayangnya, kebijakan tersebut tidak pernah direkognisi di dalam peraturan perundangundangan apapun sejak masa awal perdamaian, termasuk di tingkat daerah. Meskipun Presiden Susilo Bambang Yudhoyono pernah mengeluarkan instruksi kepada BPN untuk menyiapkan mekanisme alokasi tanah (lihat Instruksi Presiden Nomor 15 Tahun 2005), kebijakan tersebut tetap menggantung karena ketiadaan panduan yang jelas.

Dari sisi kelembagaan, pemerintah Aceh berinisiatif membentuk Badan Reintegrasi Aceh (BRA) beberapa bulan setelah penandatanganan perjanjian damai. Tugas BRA adalah menjalankan misi reintegrasi dan program-program penguatan perdamaian, termasuk penyediaan tanah pertanian. Anggota lembaga nonstruktural ini terdiri atas perwakilan GAM, masyarakat sipil, lembaga swadaya masyarakat, birokrat, dan akademisi (Sujatmiko, 2012). Namun, keberadaan BRA baru diakui oleh peraturan daerah Aceh (qanun) pada tahun 2015.

Selama 12 tahun setelah terbentuknya BRA, program penyediaan tanah pertanian tersendat. Fokus kegiatan yang dilakukan oleh BRA, terutama di masa awal perdamaian, justru lebih terkonsentrasi pada pembangunan rumah dan penyaluran bantuan finansial (Avonius, 2011). Tugas alokasi tanah sulit dilakukan oleh BRA secara independen mengingat lembaga ini tidak memiliki peran dan kapabilitas 
dalam mensinergikan sasaran yang diinginkan dengan melibatkan seluruh stakeholder terkait. Selain itu, keterbatasannya juga terkait dengan kewenangan dalam pengelolaan bidang pertanahan, dimana hal tersebut masih menjadi wewenang utama pemerintah pusat melalui Kementerian Agraria dan Tata Ruang/Badan Pertanahan Nasional (Kementerian ATR/BPN) pada kategori tanah nonhutan atau Areal Penggunaan Lain (APL) dan Kementerian Lingkungan Hidup dan Kehutanan (KLHK) pada kategori tanah hutan.

Realisasi MoU Helsinki ayat 3.2.5 dapat disinkronisasi dengan reforma agraria (Gambar 2). Penyediaan tanah pertanian untuk masyarakat yang terkait dengan GAM dan korban konflik mengadopsi konsep penataan aset. Selanjutnya, penerima tanah menerima bantuan pemberdayaan melalui penataan akses. Reforma agraria dan MoU Helsinki memang memiliki perbedaan tujuan utama, tetapi penyelarasan keduanya akan berkontribusi terhadap penguatan fondasi perdamaian di Aceh. Reforma agraria juga mendukung pemerintah untuk mengatasi kemiskinan yang sudah mengakar di Aceh sejak masa konflik.

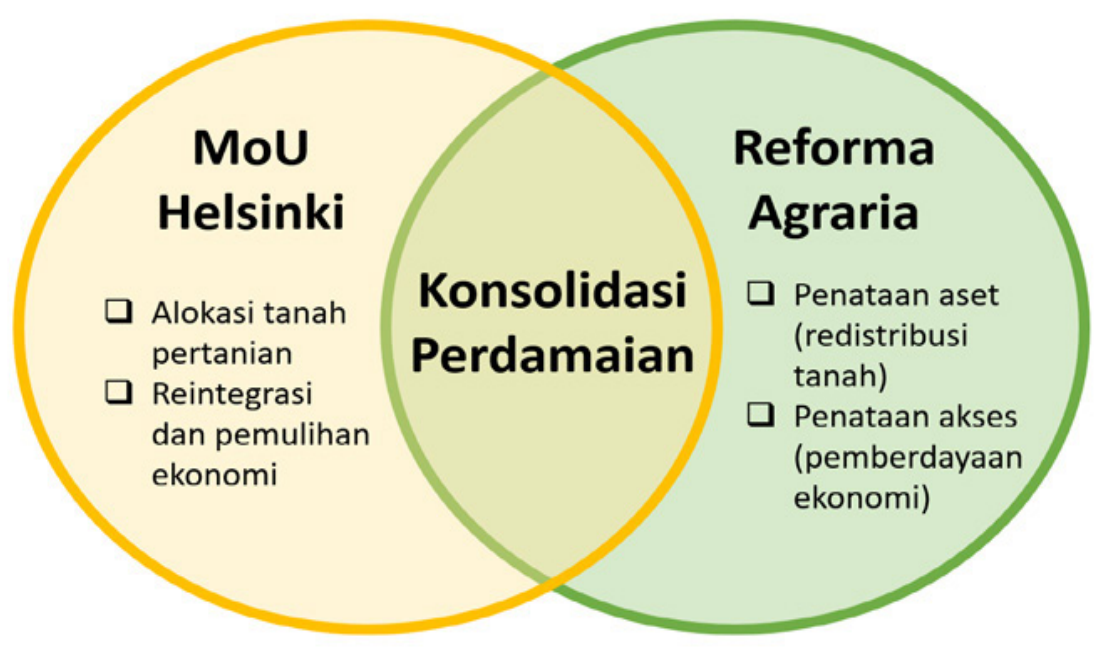

Gambar 2. Strategi Konsolidasi Perdamaian Berbasis Tanah di Aceh

Berkaitan dengan penataan aset, Perpres 86/2018 mengatur 11 sumber objek redistribusi tanah atau disebut sebagai Tanah Objek Reforma Agraria (TORA). Sebelum dialokasikan, TORA mengalami serangkaian prosedur tertentu agar clean and clear. Sertipikat hak milik akan diberikan setelah tanah didistribusi sebagai bukti legalitas kepemilikan tanah dalam rangka memberikan jaminan kepastian dan perlindungan hukum kepada pemegang haknya.

Tanah yang sudah diberikan harus dimanfaatkan untuk penggunaan pertanian oleh pemiliknya agar produktif. Hal ini tergolong sebagai kegiatan kunci karena peningkatan kesejahteraan pemilik tanah bergantung pada hasil pengusahaan tanah. Pemerintah turut membantu melaksanakan penataan akses, yang jika merujuk pada Perpres 86/2018 terdiri atas: (1) pemetaan sosial, (2) peningkatan kapasitas kelembagaan, (3) pendampingan usaha, (4) peningkatan keterampilan, (5) penggunaan teknologi tepat guna, (6) diversifikasi usaha, (7) fasilitasi akses permodalan, (8) fasilitasi akses pemasaran (offtaker), (9) penguatan basis data dan informasi komoditas, serta (10) penyediaan infrastruktur pendukung.

Perpres 86/2018 mengeluarkan terobosan dari segi kelembagaan pelaksanaan reforma agraria dengan dibentuknya Tim Reforma Agraria. Tim ini dibantu oleh unsur pelaksana Gugus Tugas Reforma Agraria (GTRA) yang mencakup level pusat, provinsi, hingga kabupaten/kota. Pelaksanaan penataan aset dan akses jelas melibatkan banyak instansi atau lembaga sehingga dibutuhkan koordinasi yang optimal. Wadah GTRA memberikan peluang integrasi antar lembaga yang bersifat vertikal dan sektoral (Luthfi, 2018). 


\section{Rencana Kegiatan Redistribusi Tanah}

Political will alokasi tanah pertanian kepada tiga kluster subjek pascakonflik dimulai sejak tahun 2019 dengan diterbitkannya Surat Edaran Nomor 100/12790 oleh Gubernur Aceh. Seluruh bupati dan wali kota diarahkan untuk menuntaskan penyediaan tanah selambat-lambatnya hingga tahun 2025. Sebagaimana yang telah dibahas sebelumnya, program reforma agraria sangat berperan dalam mengakselerasi kebijakan ini sebab skenario pelaksanaan redistribusi tanah telah dibangun dengan matang (Gambar 3).

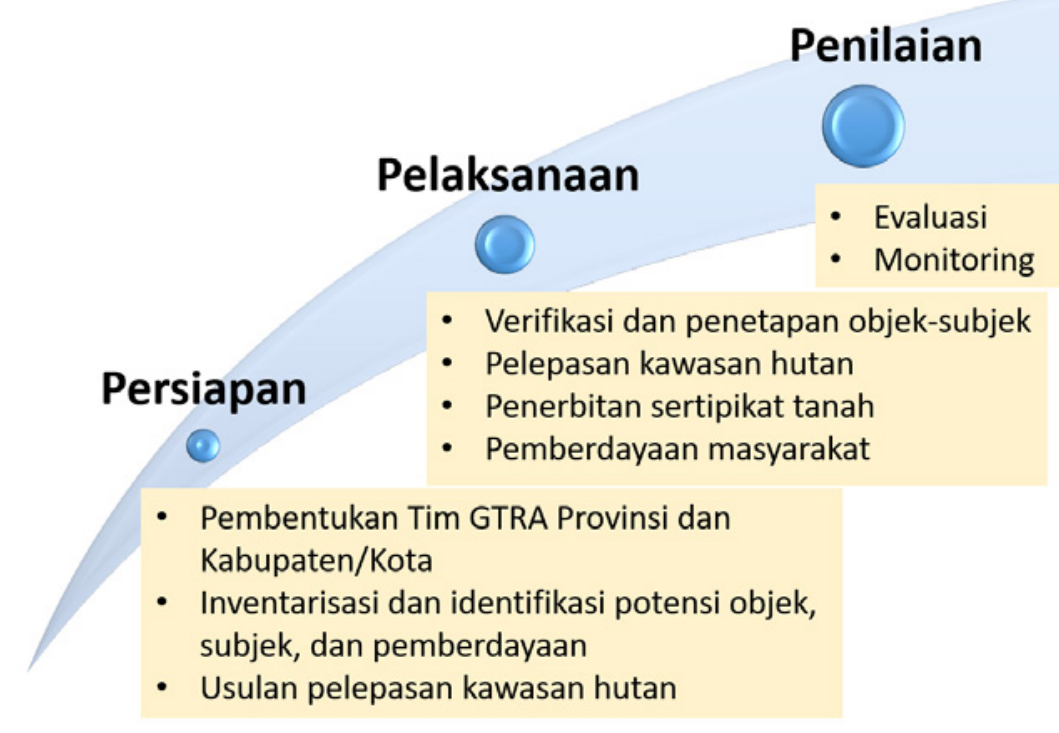

Gambar 3. Roadmap Kegiatan Redistribusi Tanah

Tahap awal kegiatan redistribusi tanah dilaksanakan melalui pembentukan Tim GTRA di tingkat provinsi dan kabupaten/kota. Karena GTRA tersusun dan melibatkan seluruh pemangku kepentingan (termasuk di dalamnya adalah BRA), adanya kerjasama dan partisipasi aktif dari setiap unsur sangat menentukan keefektifan program. Kelembagaan GTRA Provinsi Aceh sendiri telah terbentuk berdasarkan Surat Keputusan Gubernur Provinsi Aceh Nomor 590/385/2019. Hal ini kemudian disusul dengan pembentukan Tim GTRA dan Pelaksana Harian GTRA, dimana masing-masing dipimpin oleh Gubernur Aceh dan Kepala Kantor Wilayah BPN Provinsi Aceh. Pada level kabupaten/kota, GTRA telah terbentuk di seluruh kabupaten/kota di Aceh.

Identifikasi subjek merupakan tugas yang krusial untuk memastikan berapa luas tanah yang harus dialokasi. Kontroversi terkait jumlah aktual penerima bantuan yang berhak telah terjadi sejak masa awal perdamaian sehingga masalah ini dinilai menjadi salah satu determinan terhambatnya redistribusi tanah. Saat pembicaraan damai, jumlah kombatan disepakati sebanyak 3.0oo orang. Namun, seiring dengan berjalannya waktu, persepsi baru mulai muncul berkaitan dengan jumlah yang seharusnya. Begitu pula dengan eks-tapol, tidak ada publikasi yang jelas mengenai data aktualnya. Kondisi yang lebih rumit terjadi pada proses pencatatan korban konflik karena belum ada parameter konkret untuk membuktikan seseorang layak dikategorikan sebagai korban. Masyarakat pada umumnya akan mengidentifikasi diri sebagai korban karena banyak dari mereka yang merasa tertindas dan terdampak secara psikis dan/atau sosial ekonomi.

Badan Reintegrasi Aceh (BRA) bertanggung jawab dalam menuntaskan proses penelusuran subjek. Agar memudahkan pendataan, BRA telah bekerjasama dengan Wali Nanggroe (lembaga kepemimpinan adat Aceh), Komite Peralihan Aceh (organisasi informal yang beranggotakan mantan kombatan GAM), Komisi 
Kebenaran dan Rekonsiliasi Aceh (lembaga yang berfungsi mengungkap pelanggaran hak asasi manusia di masa lalu), dan pihak-pihak eksternal lainnya. Keterbukaan dan transparansi data sangat dibutuhkan di dalam proses tersebut. Hingga saat ini, BRA sudah mendata lebih dari 6o ribu calon penerima di seluruh kabupaten/kota. Jumlah terbesar terdapat di kelompok korban konflik, disusul oleh mantan kombatan dan tapol secara berurutan. Subjek yang sudah diinventarisasi tersebut masih perlu diverifikasi agar didapatkan data yang valid sebelum ditetapkan oleh bupati atau wali kota di masing-masing daerah. Selain itu, penetapan subjek juga harus menyesuaikan ketentuan kriteria sesuai petunjuk di dalam Perpres 86/2018 karena subjek yang berhubungan dengan konflik tidak diatur secara spesifik di peraturan tersebut.

Potensi lokasi redistribusi tanah diinventarisasi dengan mengacu pada sumber TORA. Data ini dapat diperoleh dari BPN, kementerian atau lembaga lain, pemerintah daerah, dan usulan dari masyarakat. Ada beberapa alternatif sumber TORA yang dapat digunakan untuk kegiatan redistribusi tanah, antara lain: (a) Tanah Negara Bebas (freshland) yang ditetapkan melalui usulan bupati atau wali kota, (b) Pelepasan Kawasan Hutan (PKH) yang ditetapkan melalui usulan Dinas Lingkungan Hidup dan Kehutanan serta Balai Pemantapan Kawasan Hutan, (c) Tanah Hak Pengelolaan tidak produktif yang ditetapkan melalui usulan Dinas Tenaga Kerja dan Mobilitas Penduduk, serta (d) Tanah Hak Guna Usaha (HGU) terlantar yang ditetapkan melalui usulan Dinas Pertanian dan Perkebunan dan berdasarkan database tanah terlantar dari BPN. Pemetaan potensi objek diikuti oleh analisis potensi pengembangan pemberdayaan dengan memperhatikan kondisi kesesuaian biofisik dan arahan tata ruang.

Luas lokasi indikatif TORA yang sudah diinventarisasi sampai saat ini mencapai lebih dari 120.000 hektare. Jika ditinjau dari persebarannya, potensi TORA didominasi oleh usulan PKH (Gambar 4). Tantangannya adalah proses pelepasan tanah dari kawasan hutan memerlukan prosedur yang lebih panjang untuk ditempuh dibandingkan dengan TORA nonhutan (APL). Bupati atau wali kota terlebih dahulu mengusulkan lokasi yang masuk di dalam kawasan hutan untuk dilakukan perubahan tata batas menjadi kawasan nonhutan kepada pihak KLHK. Sementara itu, potensi TORA dari APL masih banyak yang perlu diverifikasi demi memastikan tidak adanya penguasaan masyarakat di tanah tersebut. Berdasarkan hasil analisis terkini, lokasi objek yang siap dilaksanakan kegiatan redistribusi (setelah tahun 2021) baru mencapai 5.548 hektare. Terkhusus di wilayah pesisir dan perkotaan, pendataan TORA sangat sulit dilakukan karena keterbatasan tanah.

Komponen kunci pelaksanaan reforma agraria adalah penataan aset dan akses. Objek yang sudah berstatus clean and clear akan diredistribusi dengan mengikuti alur tertentu sampai tahap pembukuan hak dan penerbitan sertipikat. Langkah ini dikoordinasikan oleh BPN. Selanjutnya, masyarakat yang telah menerima tanah diberikan bantuan modal dan bimbingan teknis melalui program-program pemberdayaan masyarakat yang dibuat oleh pemerintah, pihak swasta, dan lembaga swadaya masyarakat. Penataan aset dan akses untuk masyarakat pascakonflik Aceh sudah dilaksanakan pada dua tahun anggaran (2019 dan 2020) di tiga daerah yaitu Kabupaten Pidie Jaya, Kabupaten Aceh Timur, dan Kabupaten Aceh Utara. Janji MoU Helsinki ayat 3.2.5 akan terus direalisasikan di seluruh Aceh hingga paling lambat pada tahun 2025.

Tahap pemantauan kegiatan redistribusi tanah tidak kalah penting dilakukan agar kegiatan tetap berada pada jalur yang tepat sesuai dengan cita-cita reforma agraria dan MoU Helsinki. Para stakeholder, terutama yang tergabung di dalam GTRA, melakukan kontrol dan pengawasan secara berkelanjutan sehingga tanah yang sudah dialokasikan benar-benar digarap dan memberikan dampak yang positif bagi penghidupan pemilik tanah. Evaluasi kegiatan mencakup mendeteksi hambatan selama program berjalan, mengidentifikasi faktor-faktor yang menyebabkan munculnya hambatan, serta memberikan bimbingan dan rekomendasi usaha perbaikan atau tambahan program di masa mendatang. Keberhasilan kegiatan juga dapat diketahui dengan menggunakan indikator terukur atau tingkat persepsi masyarakat terhadap perbaikan perekonomian di masa perdamaian melalui redistribusi tanah pertanian. 


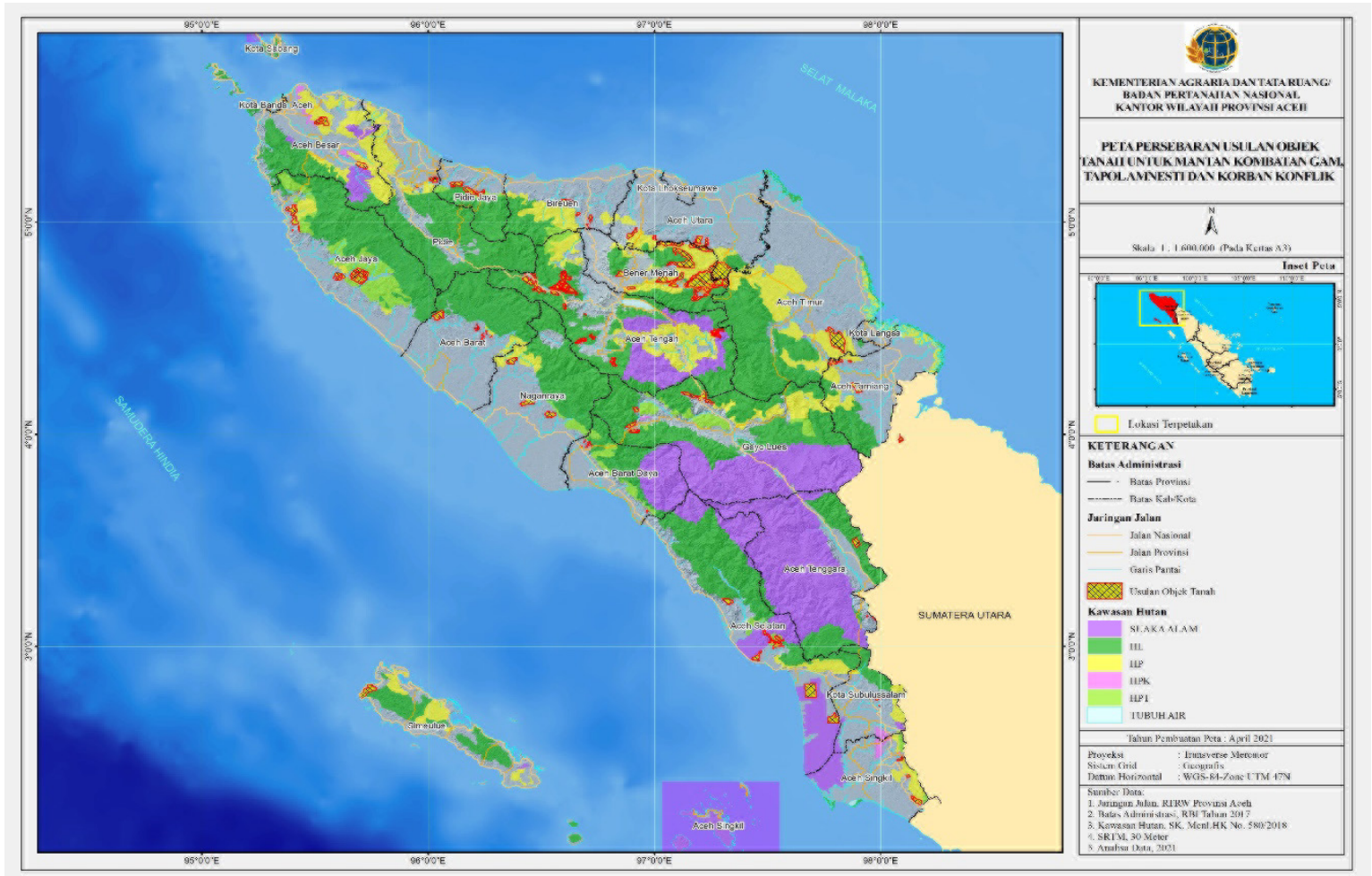

Gambar 4. Peta Potensi Lokasi Redistribusi Tanah

Sumber: Kantor Wilayah BPN Provinsi Aceh, 2021

\section{Capaian Terkini Penataan Aset dan Akses}

Komitmen penyelesaian redistribusi tanah pertanian untuk mantan kombatan, tapol yang memperoleh amnesti, dan korban konflik telah dibangun lebih serius sejak dikeluarkannya arahan percepatan dari gubernur pada tahun 2019. Di dalam setiap rapat koordinasi Gugus Tugas Reforma Agraria tingkat provinsi, salah satu agenda tahunan untuk memperoleh kesepakatan terkait arah kebijakan reforma agraria, redistribusi tanah dari MoU Helsinki menjadi salah satu pembahasan yang vital. Seluruh daerah setidaknya mulai bergerak untuk mengidentifikasi subjek dan mengusulkan potensi TORA yang tersedia.

Hingga tahun 2020, redistribusi tanah sudah terlaksana untuk 230 subjek yang tersebar di tiga daerah, yaitu Kabupaten Pidie Jaya, Kabupaten Aceh Timur, dan Kabupaten Aceh Utara (Tabel 1). Capaian tersebut tentunya masih jauh dari sasaran, tetapi langkah yang sudah ada ini diharapkan dapat memberikan manfaat sosial-ekonomi yang positif secara perlahan. Redistribusi tanah tidak berhenti pada sertipikasi tanah saja, tetapi juga ditambah dengan rencana pemberdayaan agar tanah yang diberikan dapat produktif. Kerjasama dan koordinasi antarpihak memiliki peranan penting dalam mendukung setiap tahapan kegiatan.

Tabel 1. Objek Tanah yang Sudah Disertipikatkan dan Diberdayakan

\begin{tabular}{|c|c|c|c|c|c|c|}
\hline \multirow{2}{*}{ Tahun } & \multicolumn{3}{|c|}{ Lokasi } & \multirow{2}{*}{$\begin{array}{c}\text { Subjek } \\
\text { (Orang) }\end{array}$} & \multirow{2}{*}{$\begin{array}{c}\text { Luas Bidang } \\
\text { (Ha) }\end{array}$} & \multirow{2}{*}{ Pemberdayaan } \\
\hline & Kabupaten & Kecamatan & Desa & & & \\
\hline 2019 & Pidie Jaya & Bandar Baru & Meunasah Abah Lueng & 100 & 201,03 & Perkebunan serai wangi \\
\hline \multirow[t]{2}{*}{2019} & \multirow[t]{2}{*}{ Aceh Timur } & \multirow[t]{2}{*}{ Birem Bayeun } & Blang Tualang & 52 & 104,00 & \multirow[t]{2}{*}{ Perkebunan kopi } \\
\hline & & & Jambo Labu & 41 & 82,00 & \\
\hline 2020 & Aceh Utara & Sawang & Riseh Tunong & 37 & 66,69 & Perkebunan kopi \\
\hline
\end{tabular}

Sumber: Kantor Wilayah BPN Provinsi Aceh, 2021 
Kabupaten Pidie Jaya adalah daerah yang pertama kali melaksanakan alokasi tanah untuk tiga kluster subjek pascakonflik. Sebanyak 100 orang telah mendapatkan tanah seluas 201,03 hektare yang terletak di kawasan perbukitan Desa Meunasah Abah Lueng, Kecamatan Bandar Baru pada tahun 2019. Pada tahun yang sama, sertipikat tanah juga telah diberikan kepada 93 orang di Kecamatan Birem Bayeun, Kabupaten Aceh Timur yang terdiri atas 52 orang di Desa Blang Tualang dan 41 orang di Desa Jambo Labu. Total luas tanah yang diberikan tersebut adalah 186 hektare. Pada tahun selanjutnya, kegiatan redistribusi tanah berhasil dilaksanakan untuk 37 subjek di Kabupaten Aceh Utara, tepatnya di Desa Riseh Tunong, Kecamatan Sawang, dengan luas tanah 66,69 hektare.

Seluruh tanah yang telah diberikan di ketiga kabupaten tersebut bersumber dari Tanah Negara Bebas (freshland). Secara tata ruang, lokasi tanah sangat mendukung untuk dikembangkan sebagai kawasan perkebunan. Oleh karena itu, di samping dilakukan sertipikasi, redistribusi tanah pertanian juga sudah dilengkapi dengan paket pemberdayaan, seperti pengembangan tanaman serai wangi di Kabupaten Pidie Jaya, serta kopi di Kabupaten Aceh Timur dan Kabupaten Aceh Utara. Pemilihan komoditas perkebunan disesuaikan dengan keinginan dari penerima tanah sendiri. Pemerintah daerah memfasilitasi penataan akses melalui pemberian bantuan bibit, pupuk, dan biaya penanaman dari dinas yang membidangi pertanian, serta pendampingan usaha dari dinas yang membidangi koperasi atau usaha mikro, kecil, dan menengah.

Berdasarkan observasi awal, para penerima tanah merasa sangat terbantu dari program reforma agraria dan sedikit demi sedikit mulai merasakan perubahan penghidupan ke arah positif. Namun, ada kendala-kendala yang masih dialami, khususnya selama masa tahap awal pemberdayaan. Permasalahan yang dialami oleh para penerima tanah mayoritas berhubungan dengan buruknya akses menuju lahan. Jalan yang rusak menghambat para petani untuk melakukan mobilitas dan mengangkut hasil panen. Selain itu, keuntungan yang diperoleh relatif rendah karena keterbatasan alat produksi dan target pemasaran. Dengan demikian, dukungan dari pemerintah, lembaga keuangan, dan investor masih harus ditingkatkan kembali sehingga manfaat yang diperoleh dari kegiatan redistribusi tanah semakin optimal.

Kegiatan redistribusi tanah untuk masyarakat pascakonflik akan terus dilaksanakan melalui program reforma agraria. Pada tahun 2021, sertipikat tanah akan diterbitkan untuk 1.245 orang, dengan rincian 755 orang di Kabupaten Pidie Jaya dan 490 orang di Kabupaten Aceh Utara. Berbeda dengan tahuntahun sebelumnya yang pemberian hak atas tanahnya bersifat individual, konsep redistribusi tanah pada tahun 2021 mulai menerapkan hak kepemilikan bersama atau penguasaan tanah secara komunal. Pola kepemilikan semacam ini memiliki beberapa kelebihan, seperti risiko komersialisasi atau alih kepemilikan lahan kecil, serta membentuk kultur kolektivitas melalui pemanfaatan dan pemerolehan hasil bersama. Ke depannya, penataan aset dan akses ini diharapkan segera terwujud pula di kabupaten/ kota lainnya di Provinsi Aceh agar perekonomian masyarakat semakin membaik disamping merawat perdamaian yang sudah dibangun.

\section{Peran Reforma Agraria terhadap Kebangkitan Aceh}

Reforma agraria merupakan instrumen utama untuk mewujudkan kesejahteraan dan keadilan sosial. Reforma agraria tidak sekadar membagi-bagikan tanah, tetapi di dalamnya terkandung substansi yang diadvokasikan dari aspek sosial, ekonomi, politik, dan lingkungan (Moyo, 2009). Berdasarkan analisis sebelumnya, konsep reforma agraria berprospek mendukung percepatan pemenuhan janji MoU Helsinki ayat 3.2.5. Tidak hanya itu, program ini dipercaya dapat mengatasi konflik tenurial antara masyarakat dan korporasi yang sering ditemui di lapangan sebagai produk dari distorsi manajemen pertanahan masa lalu. 
Provinsi Aceh sempat terpuruk akibat krisis kemanusiaan berkepanjangan. Penderitaan masyarakat semakin bertambah setelah tsunami besar menghancurkan pesisir barat dan timur Aceh. Dua bencana tersebut menjadi faktor utama Aceh diklasifikasikan sebagai salah satu daerah dengan tingkat kemiskinan tertinggi di Indonesia. Selama masa perdamaian, Provinsi Aceh mulai berbenah dan mengejar ketertinggalan. Berdasarkan Gambar 5, tren persentase kemiskinan cenderung menurun. Sayangnya, tingkat kemiskinan tersebut belum mampu turun hingga di bawah rata-rata nasional. Fenomena ini seakan memberikan sebuah pertanyaan besar: Mengapa Aceh masih lekat dengan kemiskinan? Padahal kini Aceh sudah menerima akses bagi hasil sumberdaya alam yang lebih besar dan juga dana otonomi khusus dari pemerintah pusat.

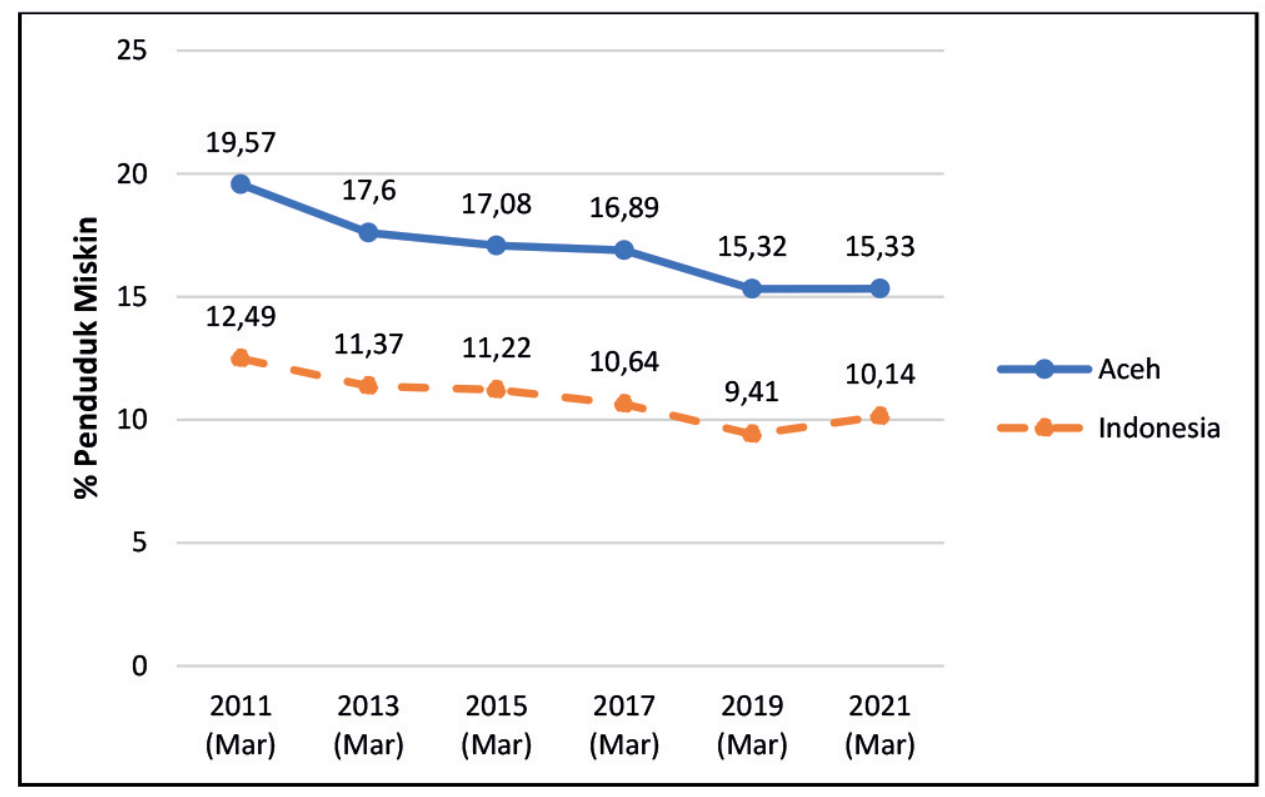

Gambar 5. Persentase Penduduk Miskin Provinsi Aceh Sumber: Badan Pusat Statistik, 2021

Reforma agraria berfungsi sebagai metode baru pengentasan kemiskinan. Strategi ini berorientasi pada akumulasi aset, dimulai dari pemberian akses tanah sebagai sumber kapital. Alfana (2014) menyebutkan bahwa peningkatan kepemilikan aset dapat membantu penghidupan rumahtangga miskin agar keluar dari strategi survival (bertahan hidup). Melalui redistribusi tanah, mantan kombatan, tapol, dan korban konflik akan memperoleh lapangan pekerjaan yang stabil. Lebih lanjut, reforma agraria memfasilitasi pemberdayaan subjek dan objek dengan pendekatan kolaboratif, melibatkan kerjasama lintas sektor sehingga hasil pembangunan dapat dicapai secara maksimal (Santosa et al., 2019).

Penjaminan hak atas tanah adalah salah satu pendekatan yang dapat diterapkan untuk manajemen tanah pascakonflik selain memperbaiki sistem administrasi pertanahan, menyelesaikan sengketa, dan merehabilitasi lahan produktif. Di beberapa negara, masyarakat yang dirugikan oleh konflik dapat mengajukan permohonan agar tanah yang sempat ditelantarkan dikembalikan ke pemiliknya melalui program restitusi (Morapedi, 2020; Mbazumutima, 2021). Hal ini tentunya membutuhkan pelibatan masyarakat yang aktif agar program tersebut dapat diimplementasikan secara efektif. Redistribusi tanah untuk mantan kombatan juga menjadi opsi pendukung reintegrasi ke dalam masyarakat sipil. Jensen et al. (2013) telah menyarankan beberapa strategi agar dari kegiatan tersebut diperoleh hasil yang diharapkan berdasarkan tahapan situasi pascakonflik. Saat transisi perdamaian, alokasi tanah kepada mantan kombatan harus diseimbangkan dengan kebutuhan kelompok rentan dan masyarakat di sekitarnya supaya tidak ada yang terdiskriminasi, serta perlunya perencanaan anggaran yang memadai. 
Sementara pada fase konsolidasi, redistribusi tanah harus dilengkapi dengan program pemberdayaan pertanian yang memadai dan penyediaan bantuan modal atau pemasaran.

Kesejahteraan masyarakat dan manajemen sumberdaya alam yang adil berasosiasi dengan keamanan negara yang stabil. Hal ini menjadi satu dari sekian alasan negara-negara yang perekonomiannya bergantung pada sumberdaya alam biasanya mengintegrasikan isu agraria di dalam penyelesaian konflik. Studi oleh Keels dan Mason (2019) menemukan bahwa penyertaan pembaruan agraria setelah perang berpotensi mengurangi risiko konflik yang berulang. Tentunya, kesuksesan tersebut hanya bisa terjadi jika disertai dengan perencanaan yang baik. Pengalaman-pengalaman di luar negeri membuktikan ketidakefektifan perencanaan pembaruan agraria pascakonflik berkontribusi terhadap gangguan keamanan. Misalnya, pelaksanaan redistribusi tanah di El Salvador memiliki banyak permasalahan, seperti kualitas tanah yang dialokasikan buruk, serta pemerintah kurang mampu menjamin legalitas dan memberikan bantuan teknis atau keterampilan sehingga banyak mantan kombatan yang kembali berbuat tindakan kriminal (Unruh \& Williams, 2013). Kasus di Senegal cukup kompleks, dimana pertikaian kembali terjadi setelah pihak pemberontak dan pemerintah gagal merundingkan kesepakatan bersama untuk menengahi permasalahan agraria (Keels \& Mason, 2019).

Dalam konteks perjanjian damai di Aceh (MoU Helsinki), penyediaan tanah pertanian merupakan hal yang paling ditekankan di ranah kebijakan agraria dengan maksud kepentingan reintegrasi dan kemudahan ekonomi. Menariknya, tidak ada pembahasan spesifik terkait keamanan kepemilikan tanah selama konflik, yang kemungkinan disebabkan oleh adanya anggapan bahwa masalah pertanahan yang berkaitan dengan konflik relatif kecil (Green, 2013). Namun, paling tidak terdapat petunjuk bahwa jaminan hak atas tanah tidak hanya difokuskan kepada eks-kombatan, tetapi juga kepada masyarakat yang terdampak. Penyediaan tanah dipandang menjadi keputusan yang tepat untuk memulihkan perekonomian karena didorong oleh tiga alasan: (1) karakteristik mata pencaharian masyarakat Aceh didominasi oleh sektor pertanian, (2) adanya peluang peningkatan kemandirian ekonomi, dan (3) tanah dapat berfungsi sebagai sumber penghidupan jangka panjang. Meskipun demikian, hal ini memerlukan metode atau pendekatan yang mampu menengahi segala tantangan yang kemungkinan dihadapi selama merealisasikan kebijakan redistribusi tanah.

Kebijakan agraria sebenarnya bukan hal yang asing dalam penyelesaian konflik di Aceh. Menurut Shohibuddin (2018), alokasi tanah pernah diimplementasikan sebagai strategi kontrakekacauan sebelum konflik GAM, seperti ketika berjalannya program rasionalisasi militer (tahun 1948) dan munculnya gerakan Darul Islam (tahun 1953-1962). Ironisnya, konflik-konflik yang pernah terjadi di Aceh selalu tidak lepas dari dimensi agraria. Kegagalan kebijakan agraria dalam mencegah konflik baru bisa jadi disebabkan oleh pola pembangunan yang belum memberikan "peace dividend" dan tidak menyentuh akar penyebab konflik (Zainal, 2016).

Pembelajaran dari Aceh, pembangunan perdamaian yang berkelanjutan tidak diperoleh dengan dialog politik semata, apalagi disertai tindakan represif. Shohibuddin (2018) juga menegaskan bahwa niat baik kebijakan agraria tidak dapat dicapai jika pelaksanaannya hanya didasarkan pada "pendekatan kompensasi” atau ditujukan untuk meredam tekanan dari pihak-pihak yang dikhawatirkan membangkitkan konflik. Dengan kata lain, perdamaian positif terbentuk bila pemerintah serius berkomitmen dalam merumuskan dan mengimplementasikan penanggulangan masalah struktural keagrariaan dalam mewujudkan kesejahteraan masyarakat.

\section{Evaluasi dan Strategi Kebijakan Selanjutnya}

Meskipun Perpres 86/2018 telah memberikan pencerahan terhadap formulasi konsep redistribusi tanah, pelaksanaan MoU Helsinki ayat 3.2.5 sejatinya belum mendapatkan legitimasi oleh legal landscape. Mekanisme alokasi tanah pertanian tidak diatur secara rinci dan jelas. Di bidang pertanahan, undang- 
undang turunan MoU Helsinki sendiri (Undang-Undang Nomor 11 Tahun 2006 tentang Pemerintah Aceh) justru hanya membahas desentralisasi urusan pertanahan, yang kemudian malah berpotensi memunculkan konflik kewenangan antara pemerintah daerah dan pusat (Fitri, 2015). Namun, pada akhirnya tema alokasi tanah pertanian pascakonflik mulai mendapatkan perhatian baru-baru ini seiring dengan adanya diskusi rancangan qanun tentang pertanahan di Aceh. Hal ini diharapkan berpeluang untuk mempercepat realisasi kebijakan agraria yang berhubungan dengan penguatan perdamaian.

Prinsip transparansi harus dikedepankan saat pendataan calon penerima tanah. Tidak ada data yang perlu disembunyikan sebagaimana pelaksanaan pemberian bantuan pada masa lalu. Penyusunan data by name by address bertujuan agar kegiatan redistribusi tanah tepat sasaran. Terkhusus pada korban konflik, pembangunan prioritas dan kriteria tertentu akan memastikan bahwa subjek yang bersangkutan layak memperoleh hak reparasi berupa tanah.

Salah satu ciri keberhasilan upaya perdamaian positif adalah tercapainya pembangunan yang inklusif. Redistribusi tanah tidak hanya diutamakan untuk golongan tertentu. Korban konflik memiliki hak yang sama dengan eks-kombatan. Bahkan, kebijakan agraria juga memperhatikan kebutuhan host community, terutama kelompok marginal (misalnya petani yang tidak memiliki tanah, kepala rumahtangga perempuan yang miskin, dan pemuda desa yang menganggur). Dominasi satu kekuatan dan pengabaian kelompok lain berisiko mengundang perselisihan baru dan konflik lebih lanjut (Unruh \& Williams, 2013).

Melihat jumlah calon subjek yang terdata sementara ini, kebutuhan luas tanah yang diredistribusi tidak mudah untuk dipenuhi sehingga diperlukan suatu kebijakan hukum yang melibatkan peran seluruh instansi terkait. Instansi yang berhubungan dengan penyediaan objek meliputi Kementerian ATR/BPN, KLHK, serta Kementerian Desa, Pembangunan Daerah Tertinggal, dan Transmigrasi (khusus pemanfaatan lahan cadangan negara). Pemerintah daerah aktif mengusulkan lokasi yang berpotensi dijadikan sebagai TORA. Catatan penting lainnya adalah penetapan lokasi harus memperhitungkan kemungkinan dampak konflik masa lalu yang berkenaan dengan tenurial, seperti penelantaran dan okupasi tanah oleh pihak "kedua", sehingga kasus tumpang tindih dan sengketa lahan dapat dicegah (Shohibuddin, 2018).

Berbicara tentang redistribusi tanah tidak akan lengkap bila tidak disertai dengan access reform. Tanah yang telah dialokasikan harus dimanfaatkan untuk kegiatan pertanian. Kepemilikannya dilarang berpindah ke pihak lain dalam jangka waktu to tahun. Kegiatan pemberdayaan sebaiknya dilaksanakan berbasis kluster komoditas dalam skala besar dengan mempertimbangkan karakteristik kesesuaian lahan dan kearifan lokal. Pemerintah dan pihak swasta memberikan dukungan dalam bentuk modal, pendampingan, dan pemasaran. Dari segi pembiayaan, access reform dapat dimaksimalkan dengan menggunakan dana otonomi khusus ketimbang hanya bergantung pada Anggaran Pendapatan dan Belanja Aceh. Selain itu, masyarakat dijadikan sebagai aktor pemberdayaan sehingga mereka ikut berpartisipasi mulai dari tahap perencanaan hingga pengawasan (Saheriyanto \& Suhaimi, 2021).

Pemerintah perlu merencanakan grand design agar reforma agraria menjadi agenda pembangunan strategis di era perdamaian. Model ini disusun di dalam perencanaan kegiatan dan penyediaan anggaran setiap instansi. Kesungguhan elit politik menentukan cepat atau lambatnya progres kegiatan redistribusi tanah. Santosa et al. (2019) juga berargumen bahwa keberhasilan reforma agraria ditentukan oleh kerjasama yang harmonis antara pemerintah pusat, pemerintah daerah, akademisi, lembaga swadaya masyarakat, dan subjek penerima manfaat. Tim GTRA menjadi wadah kolaborasi para stakeholder untuk mengidentifikasi permasalahan redistribusi tanah. Sampai tahun 2021, GTRA kabupaten/kota telah terbentuk di seluruh Provinsi Aceh. Kelembagaan GTRA harus eksis dan terus dimaksimalkan perannya dalam menyukseskan Program Reforma Agraria sehingga integrasi penataan aset dan akses dapat berjalan lebih efektif dan efisien. 


\section{Kesimpulan}

Progres perdamaian di Provinsi Aceh telah menunjukkan capaian yang mengesankan. Namun, penyediaan tanah pertanian untuk mantan kombatan, tapol yang memperoleh amnesti, dan korban konflik, sebagaimana disepakati di dalam MoU Helsinki tahun 2005, sempat terabaikan selama bertahuntahun. Dengan adanya komitmen reforma agraria, isu ini mulai mendapatkan perhatian serius. Tulisan ini membuktikan bahwa kebijakan agraria perlu diarusutamakan di dalam konteks pembangunan perdamaian. Alokasi tanah membantu memperlancar proses reintegrasi dan memperbaiki penghidupan yang sempat terganggu selama konflik. Para subjek juga memperoleh legalitas atas kepemilikan tanah dan bantuan pemberdayaan. Selain itu, program reforma agraria mengkonsep kelembagaan GTRA yang terdiri atas para stakeholder dari berbagai bidang dan memiliki peran spesifik untuk mendukung tahapan redistribusi tanah sesuai fungsinya masing-masing. Namun, studi ini juga menemukan sejumlah permasalahan, seperti belum adanya peraturan perundang-undangan yang secara khusus mengatur penyediaan tanah pertanian untuk tiga kelompok subjek MoU Helsinki, serta hambatan dalam mengidentifikasi potensi subjek dan objek.

Dari tahun 2019 hingga tahun 2020, redistribusi tanah pertanian untuk pemenuhan kesepakatan MoU Helsinki telah dilaksanakan terhadap 230 orang. Capaian tersebut masih jauh dari sasaran sehingga dibutuhkan upaya serius supaya kegiatan ini selesai terlaksana paling lambat sampai tahun 2025. Kebijakan redistribusi tanah diharapkan dapat membantu mentransformasikan penghidupan masyarakat ke situasi yang lebih baik dan damai.

Kasus di Aceh dapat dianggap sebagai best practice kebijakan agraria dalam kerangka merawat perdamaian dan menjaga persatuan negara. Hal ini menunjukkan bahwa pembaruan agraria tidak dapat dipisahkan dari agenda pembangunan. Kesenjangan kesejahteraan dan ketidakmerataan distribusi hasil sumberdaya terbukti seringkali memicu konflik vertikal. Persoalan agraria di Aceh tentunya bukan sebatas belum terpenuhinya kompensasi penyediaan tanah, tetapi harus dipandang dari perspektif yang lebih luas. Dengan demikian, pembangunan berbasis conflict-sensitive approach harus didorong lebih kuat agar konsolidasi perdamaian tercapai dan konflik baru tidak muncul kembali ke permukaan.

\section{E. Ucapan Terima Kasih}

Penulis mengucapkan terima kasih kepada staf dan konsultan perorangan Bidang Penataan dan Pemberdayaan, Kantor Wilayah BPN Provinsi Aceh yang telah membantu mengumpulkan data penelitian.

\section{Daftar Pustaka}

Alfana, M.A.F. (2014). Strategi penghidupan rumahtangga miskin perdesaan (kasus di tiga desa Kabupaten Kulon Progo Daerah Istimewa Yogyakarta) (Tesis S-2). Universitas Gadjah Mada. Yogyakarta.

Amri, I., \& Giyarsih, S.R. (2021). Monitoring urban physical growth in tsunami-affected areas: A case study of Banda Aceh City, Indonesia. GeoJournal. https://doi.org/10.1111/10.1007/s10708-02010362-6.

Avonius, L.M. (2011). Reintegration: BRA's roles in the past and its future visions. Crisis Management Initiative, Helsinki.

Certini, G., Scalenghe, R., \& Woods, W.I. (2013). The impact of warfare on the soil environment. Earth Science Review, 127, 1-15. https://doi.org/10.1016/j.earscirev.2013.08.009.

Eklund, L., Degerald, M., Brandt, M., Prishchepov, A.V., \& Pilesjö, P. (2017). How conflict affects land use: Agricultural activity in areas seized by the Islamic State. Environmental Research Letters, 12, 054004. https://doi.org/10.1088/1748-9326/aa673a. 
Fitri, R. (2015). Potensi konflik pemerintah Aceh dan pusat dalam bidang pertanahan. Kanun Jurnal Ilmu Hukum, 66 (17), 247-275.

Green, A. (2013). Title Wave: Land Tenure and Peacebuilding in Aceh. In J. Unruh \& R.C. Williams (Eds.), Land and Post-Conflict Peacebuilding. London: Earthscan.

Harrowell, E., \& Özerdem, A. (2019). Understanding the dilemmas of integrating post-disaster and postconflict reconstruction initiatives: Evidence from Nepal, Sri Lanka and Indonesia. International Journal of Disaster Risk Reduction, 36, 101092. https://doi.org/10.1016/j.ijdrr.2019.101092.

Jensen, D., Crawford, A., Whitten, P., \& Bruch, C. (2013). Policy brief 3: Land and post-conflict peacebuilding. Diakses tanggal 11 Juli 2021 dari https://www.environmentalpeacebuilding.org/ library/policy-briefs/brief-3/

Keels, E., \& Mason, T.D. (2019). Seeds of peace? Land reform and civil war recurrence following negotiated settlements. Cooperation and Conflict, 54 (1), 44-63. https://doi.org/10.1177/0010836717750201.

Krieger, T., \& Meierrieks, D. (2016). Land grabbing and ethnic conflict. Homo Oeconomicus, 33, 243-26o. https://doi.org/10.1007/s41412-016-0025-0.

Luthfi, A.N. (2018). Reforma kelembagaan dalam kebijakan Reforma Agraria era Joko Widodo-Jusuf Kalla. BHUMI: Jurnal Agraria dan Pertanahan, 4 (2), 140-163. https://doi.org/10.31292/jb.v4i2.276.

Mbazumutima, T. (2021). Land restitution in postconflict Burundi. International Journal of Transitional Justice, 15 (1), 66-85. https://doi.org/10.1093/ijtj/ijaa031.

Mohajan, H.K. (2018). Qualitative research methodology in social sciences and related subjects. Journal of Economic Development, Environment, and People, 7 (1), 23-48. https://doi.org/10.26458/jedep. v7i1.571.

Morapedi, W.G. (2020). Land restitution and the communities of North-Eastern Botswana, 1889-2012. South African Historical Journal, 72 (3), 520-545. https://doi.org/10.1080/02582473.2020.1782456.

Moyo, S. (2009). Designing and Implementing Redistributive Land Reform: The Southern African Experience. In H.P. Biswanger-Mkhize, et al. (Eds.), Agricultural Land Redistribution: Toward Greater Consensus. Washington, DC: The World Bank.

Mwesigye, F., \& Matsumoto, T. (2016). The effect of population pressure and internal migration on land conflicts: Implications for agricultural productivity in Uganda. World Development, 79, 25-39. https://doi.org/10.1016/j.worlddev.2015.10.042.

Nazaruddin, M., Nirzalin, Sukmawati, C., \& Nasution, A.A. (2016). Reintegration and socio-economic transformation for ex-combatants of the Free Aceh Movement (Gam) post-conflict era in North Aceh-Indonesia. Advances in Social Science, Education and Humanities Research, 81, 528-539. https://doi.org/10.2991/icosop-16.2017.73.

Nurjannah. (2014). Undang-Undang Pokok Agraria (UUPA) sebagai induk landreform. Al-Daulah: Jurnal Hukum Pidana dan Ketatanegaraan, 3 (2), 193-205.

Pritchard, M.F. (2013). Land, power and peace: Tenure formalization, agricultural reform, and livelihood insecurity in rural Rwanda. Land Use Policy, 30 (1): 186-196. https://doi.org/10.1016/j. landusepol.2012.03.012.

Puri, W.H., Mahsun, M., \& Muhajir, M. (2014). Permasalahan sektoralisme kelembagaan agraria di Indonesia. STPN Press \& PPPM-STPN, Yogyakarta.

Resosudarmo, B.P. (2017). Reconstruction and Rehabilitation after Large-Scale Natural Disasters: Lessons from the Indian Ocean Tsunami in Aceh and Nias, Indonesia. In S. Tokunaga, \& B.P. Resosudarmo (Eds.), Spatial Economic Modelling of Megathrust Earthquake in Japan: Impacts, Reconstruction, and Regional Revitalization. Singapore: Springer.

Ruhimat, M. (2015). Tekanan penduduk terhadap lahan di Kecamatan Sukaraja Kabupaten Sukabumi. Gea: Jurnal Pendidikan Geografi, 15 (2), 59-65. https://doi.org/10.17509/gea.v15i2.3548.g2527.

Saheriyanto, \& Suhaimi, A. (2021). Pendampingan dan akses modal sebagai strategi access reform dari tanah pelepasan kawasan hutan di Kabupaten Barito Kuala. Jurnal Pertanahan, 11 (1), 76-88. 
Salim, M.N., \& Utami, W. (2019). Reforma Agraria, menyelesaikan mandat konstitusi: Kebijakan Reforma Agraria dan perdebatan Tanah Objek Reforma Agraria. STPN Press, Yogyakarta.

Santosa, S., Wicaksono, A., \& Nugroho, R. (2019). Multi-role collaboration of ministries and institutions in the implementation of agrarian reform in Indonesia. BHUMI: Jurnal Agraria dan Pertanahan, 5 (3), 9-18. https://doi.org/10.31292/jb.v5i3.384.

Schulze, K.E. (2004). The Free Aceh Movement (GAM): Anatomy of a separatist organization. East-West Center Washington, Washington, D.C., USA.

Shohibuddin, M. (2018). Perspektif agraria kritis: Teori, kebijakan dan kajian empiris. STPN Press, Yogyakarta.

Sujatmiko, I.G. (2012). Conflict transformation and social reconciliation: The case of Aceh, Indonesia. Asian Social Science, 8 (2), 104-111. http://dx.doi.org/10.5539/ass.v8n2p104.

Trijono, L. (2009). Pembangunan perdamaian pasca-konflik di Indonesia: Kaitan perdamaian, pembangunan dan demokrasi dalam pengembangan kelembagaan pasca-konflik. Jurnal Ilmu Sosial dan Ilmu Politik, 13 (1), 48-70.

Unruh, J., \& Williams, R.C. (2013). Lesson Learned in Land Tenure and Natural Resource Management in Post-Conflict Societies. In J. Unruh \& R.C. Williams (Eds.), Land and Post-Conflict Peacebuilding. London: Earthscan.

Wennmann, A., \& Krause, J. (2009). Managing the economic dimensions of peace processes: Resource wealth, autonomy, and peace in Aceh. CCDP Working Paper No. 3. Geneva: CCDP.

Wiradi, G. (2009). Reforma Agraria: Perjalanan yang belum berakhir. Sajogyo Institute, Akatiga, \& Konsorsium Pembaruan Agraria, Jawa Barat.

World Bank. (2007). 2006 Village Survey in Aceh: An assessment of village infrastructure and social conditions. World Bank, Washington, D.C., USA.

Zainal, S. (2016). Transformasi konflik Aceh dan relasi sosial-politik di era desentralisasi. MASYARAKAT: Jurnal Sosiologi, 21 (1), 81-108.

Zeccola, P. (2011). Dividing disasters in Aceh, Indonesia: Separatist conflict and tsunami, human rights and humanitarianism. Disasters, 35 (2), 308-328. https://doi.org/10.1111/j.0361-3666.2010.01213.x. 